\title{
Seasonal Partitioning of Primary Production and Biomass between Phytoplankton and Metaphyton in a Shallow Lake Agmon, Hula Valley (Israel)
}

\author{
Y. Yehoshua1, M. Gophen ${ }^{2 *}$ \\ ${ }^{1}$ The Mina and Everard Goodman Faculty of Life Sciences, Bar-Ilan University, Ramat-Gan, Israel \\ ${ }^{2}$ MIGAL Scientific Research Institute, Kiryat Shmona, Israel \\ Email: Yehoshy@mail.biu.ac.il, *Gophen@Migal.org.il
}

How to cite this paper: Yehoshua, Y. and Gophen, M. (2018) Seasonal Partitioning of Primary Production and Biomass between Phytoplankton and Metaphyton in a Shallow Lake Agmon, Hula Valley (Israel). Open Journal of Modern Hydrology, 8, 66-81.

https://doi.org/10.4236/ojmh.2018.82006

Received: March 25, 2018

Accepted: April 22, 2018

Published: April 25, 2018

Copyright $\odot 2018$ by authors and Scientific Research Publishing Inc. This work is licensed under the Creative Commons Attribution International License (CC BY 4.0).

http://creativecommons.org/licenses/by/4.0/

\begin{abstract}
Agmon is a small, shallow man-made lake (area: $1.1 \mathrm{~km}^{2}$; mean depth $0.45 \mathrm{~m}$ ), excavated in the peat soils of the Hula Valley in northern Israel, that was filled with water in August 1994. We followed the seasonal variations in phytoplankton and metaphyton biomass, primary production and related environmental conditions between December 1995 and July 1997. Water temperature ranged between $9.5^{\circ} \mathrm{C}-30.8^{\circ} \mathrm{C} ; \mathrm{pH}$ ranged between 7.2 - 8.6. The algae in Lake Agmon were characterized by seasonal alterations between summer-fall phytoplankton blooms and spring proliferation of benthic algal mats, with a winter clear-water phase. Chlorophyll a content in the water, as a measure of planktonic algal biomass, was low in winter $\left(1.75-5 \mu \mathrm{g} \cdot \mathrm{L}^{-1}\right)$ and high in summer (>100 $\left.\mu \mathrm{g} \cdot \mathrm{L}^{-1}\right)$, when planktonic cyanobacteria (Microcystis spp.) bloomed. Metaphyton biomass varied between 3.5 and $970 \mathrm{~g} \cdot \mathrm{dry} \cdot \mathrm{wt} \cdot \mathrm{m}^{-2}$, with chlorophyll a content ranging from $5-701 \mathrm{mg} \cdot \mathrm{m}^{-2}$. The dominant benthic algal genera were Spirogyra and Oedogonium in 1996 and Cladophora in 1997. Phytoplankton primary production was high in summer-fall, with a maximum of $1200 \mathrm{mg} \cdot \mathrm{O}_{2} \cdot \mathrm{m}^{-2} \cdot \mathrm{h}^{-1}$. Benthic primary production was high from March till May, with a peak of $2173 \mathrm{mg} \cdot \mathrm{O}_{2} \cdot \mathrm{m}^{-2} \cdot \mathrm{h}^{-1}$ in April 1997. The rate of benthic algal primary production was positively correlated to benthic chlorophyll a $\left(\mathrm{r}^{2}=0.90\right)$. Diel measurements of water column dissolved oxygen (DO) concentration, conducted monthly from January to May 1997, revealed that DO concentration ranged from a nighttime minimum of 5.3 to a noon peak of $15.3 \mathrm{mg} \cdot \mathrm{L}^{-1}$. Only during January to February, no significant changes in DO with depth were found, suggesting that at that time the water column was well mixed. The most salient feature of primary production in the lake
\end{abstract}


was the seasonal partitioning between its benthic and planktonic components. This was most evident in the significant inverse relationship between benthic and planktonic primary productivity rates $\left(r^{2}=0.78\right)$.

\section{Keywords}

Chlorophyll a, Agmon, Metaphyton, Phytoplankton, Primary

Production

\section{Introduction}

During the last 80 years, the Lake Kinneret Drainage Basin ecosystems have undergone significant anthropogenic and natural modifications. Prior to the 1950s, the Hula Valley was mostly (6500 ha) covered with old Lake Hula (1300 ha) and swampy wetlands. This area was not cultivated, malaria was common, and water loss by Evapotranspiration was high. Man-made operations in the drainage basin and, accompanied by natural climatic conditions, resulted in modifications of the ecosystem structure. The Jordan River crossing the Hula Valley contributes about $63 \%$ of the downstream of the Lake Kinneret's water budget, but $70 \%$ of the total nutrient inputs, of which over $50 \%$ originate in the Hula Valley region, including the valley and the slopes on both sides (East and West) of it. Old Lake Hula and swamps were drained and were being converted for agricultural development. Years later, land utilization was modified in an operation referred to as the Hula Reclamation Project (HRP) which was improved later [1]. The Hula Reclamation Project included: Creation of a new shallow lake Agmon (surface area of 110 ha, mean depth: $0.45 \mathrm{~m}$., volume: $0.44 \times 10^{6} \mathrm{~m}^{3}$ ), renewal of $90 \mathrm{~km}$ drainage and water supply canals, placing a vertical plastic barrier along $2.8 \mathrm{~km}$ crossing the valley from east to west, maintenance of higher underground water table and functional conversion of 500 ha with lake Agmon in the center from agricultural to eco-tourism usage [1]. The objectives of Lake Agmon creation were aimed at: 1) Nutrients removal from the Lake Kinneret external loads; 2) Producing an ecological component for eco-tourism; 3) Principle component for the hydrological management and agricultural irrigation system for the entire valley. Immediately after filling water in Lake Agmon (1994), it was a subject for monitoring and research aimed at evaluating an optimal model of operation. Optimized model of the management of Lake Agmon took into account the following objectives: improvement of irrigation water supply, maintenance of high underground water table ensuring peat soil moisture to prevent its deterioration, and the achievement of a high diversity of re-establishment of natural flora and fauna emphasizing aquatic birds and their nesting activity. Regimes of nutrient inputs into Lake Kinneret were changed by a decline in Nitrogen influx accompanied by air temperature increase.

Prior to the drainage of old Lake Hula and adjacent swamps during 1950-1957, Nitrogen was fluxed from the basin to lake Kinneret, mostly as high- 
ly bio-available Ammonia, but after the Hula drainage, the dominant $\mathrm{N}$ was modified to Nitrate. Before the mid-1990's, a daily volume of $25 \times 10^{3} \mathrm{~m}^{3}$ of raw sewage and Fishpond (1700 ha) effluents, rich with ammonia, influxed into lake Kinneret. The fishpond area was dramatically reduced (450 ha), as well as their effluents, and the raw sewage was stored in reservoirs and reused. During 40 years after the Hula Valley drainage, the area was successfully cultivated, agricultural products were economically produced, and the nutrient flux into Lake Kinneret did not threaten its water quality. Nevertheless, as a result of inappropriate irrigation and agricultural methods, the peat soil quality deteriorated by consolidation and destruction. It was accompanied by heavy dust storms, subsidence of soil surface, blocking of drainage canals, enhancement of underground fires, and outbreaks of rodent populations. These deteriorated processes caused severe damage to agricultural crops and 500 ha of the deteriorated land were ignored. A reclamation project (Hula Reclamation Project, HRP) was consequently implemented [2].

The reclamation project (Hula Project) was implemented, aimed at reducing the nutrient fluxes from Hula soil while retaining the economic utilization of the land through a shift from conventional agriculture to eco-tourism. Because of the many implications, of ecological modifications it was accompanied by intensive research to ensure that they are indeed advancing the program's three main objectives: maintaining economically viable agriculture and eco-tourism, preventing pollutant inputs from reaching Lake Kinneret, and conservation of the region's unique and fragile ecosystem.

A research was carried out, aimed at several aspects of ecology including this study of Periphyton Primary Production presented in this paper.

Lake Agmon (Figure 1) receives its water from the Jordan River, which brings low-saline, P-enriched water originating from Mount Hermon. More saline waters that are also enriched with sulfate, iron, calcium, and humic acids flow into the lake from a canal that drains the peatlands north of Agmon [3]. Additional input of peat waters is via groundwater seepage [4]. The impact of the Calcium (as Gypsum) rich input water inputs is known to have an impact on "Calcareous Periphyton" [5].

A multidisciplinary monitoring program initiated in 1993 was designed to characterize water quality in the Hula Valley prior to the creation of Agmon, and then to follow the development of Agmon from the day of its filling. The program was aimed at learning the biogeochemical structure and functioning of this new ecosystem, and providing the scientific basis for its future management.

In the course of this program, the algal populations were found to alternate seasonally between phytoplankton dominance in summer-fall and phytobenthos dominance in spring, and they reflect hypertrophic conditions [6]. The annual cycle went through three distinct phases:

1) A clear-water phase with low algal biomass, from January-February;

2) A benthic mat phase or, according to the terminology of Crumpton (1989), a metaphyton dominance phase, from March-June; 


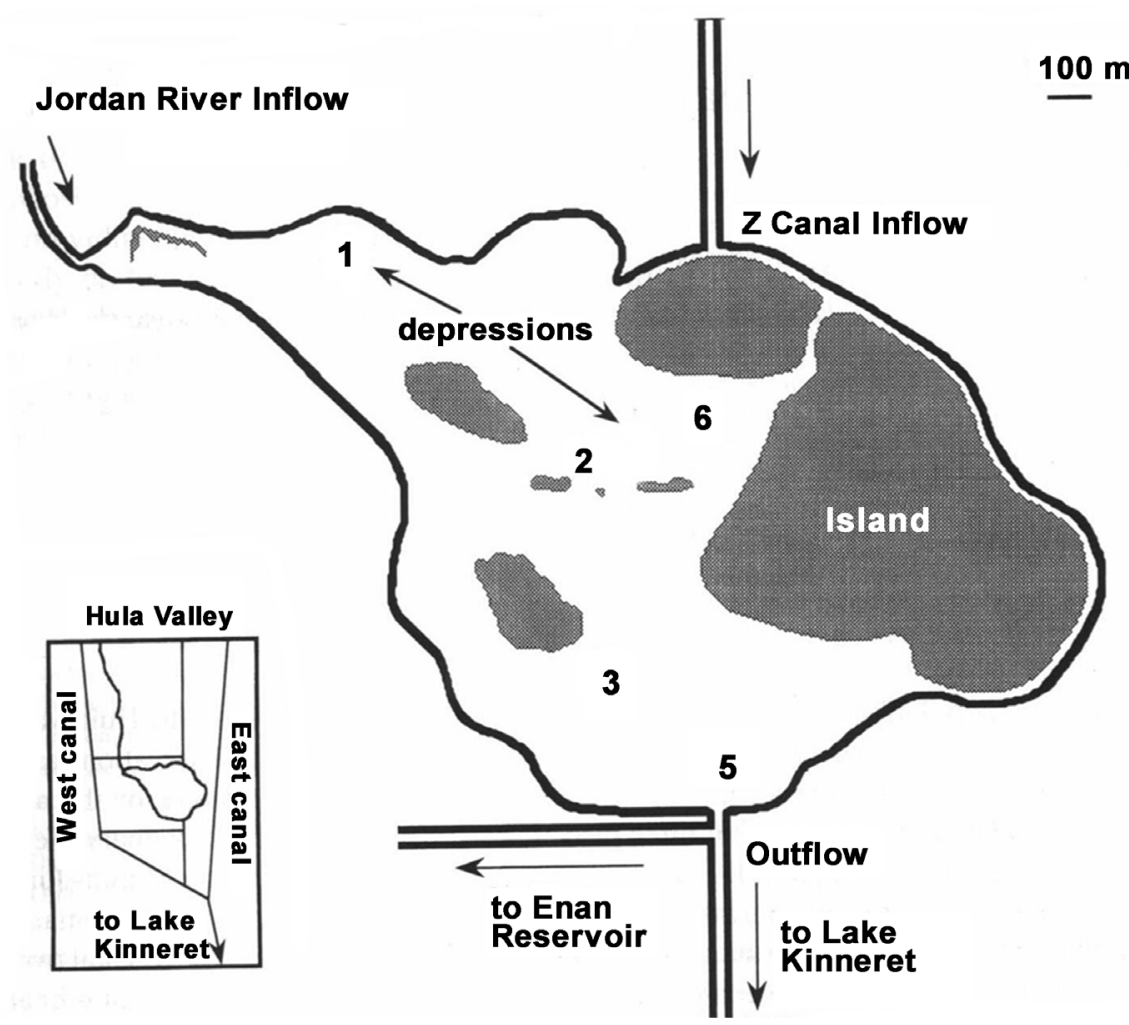

Figure 1. Map of Lake Agmon showing the sampling stations. The map is modified from Hambright et al. (1998).

3) A phytoplankton bloom phase during June-December [6].

In this study, we investigated the seasonal dynamics of photosynthesis by those two algal groups: the phytoplankton and the metaphyton.

\section{Methods}

\subsection{Monthly Sampling for Algal Biomass and Associated Field Measurements}

Water samples for determination of phytoplankton chlorophyll a (Chl), primary production, and dissolved oxygen (DO) were collected monthly from December 1995 until July 1997 with a Van Dorn sampler from a mid-water column depth at station 5 in the southern part of Lake Agmon (Figure 1). In 1996, water was also sampled at station 2 in the northern part. In 1997, station 2 was replaced by station 1, further to the north (Figure 1). During transportation to the lab, water samples were kept cooled and in the dark. All DO analyses were completed within $48 \mathrm{~h}$. At the time of sampling, water depth at the sampling site was determined, and depth profiles ( $10 \mathrm{~cm}$ intervals) of temperature (YSI model 54RC) and light intensity (Li 1858, Li-Cor light meter) were recorded. Water transparency was measured with a Secchi disk [7]

Samples for the analysis of benthic algal biomass (as Chl and dry weight) were taken monthly at station 5 during the metaphyton bloom seasons, from March to June in 1996 and again from February to July in 1997, as well as at station 1 
from February to July in 1997. Due to pronounced spatial variability, 5 replicate samples were taken for biomass estimates each sampling time. In 1996, samples were collected with a sharp-edge metal hollow cylinder, $42 \mathrm{~mm}$ in diameter. In 1997, the bell jar (diameter: $22.5 \mathrm{~cm}$ ) used for measuring benthic primary production (see later) was used instead of the hollow cylinder. All benthic algae contained within the bell jar were collected by sharp knife.

\subsection{Diel Changes in $\mathrm{O}_{2}$ Concentration and Temperature}

From January to May 1997, diel cycles of water column temperature and oxygen concentration were measured monthly at stations 1 and 5 using the above YSI oxygen and temperature meter. Measurements were taken from the top, middle, and bottom of the water column, 5 times during a diel cycle, dawn and dusk were always included.

\subsection{Biomass Determination}

Phytoplankton-Chl concentration in water samples was measured fluorometrically [8]. Water samples $(10-25 \mathrm{ml})$ were filtered onto GF/C Whatman filters. The filters were crashed with Teflon-glass homogenizers and extracted in $90 \%$ acetone overnight in the dark at $4{ }^{\circ} \mathrm{C}$. Chlorophyll a concentration was read on a fluorometer.

Metaphyton-Metaphyton samples were washed of particulate matter with distilled water. For Chl determination, about $1 \mathrm{~g}$ of each sample was extracted in $90 \%$ cold acetone. The sample was sonicated 4 times, $30 \mathrm{~s}$ each. The amount of $\mathrm{Chl}$ in the extract was determined by measuring the optical density with a Varian spectrophotometer DMS-100 - 200, UV-visible with 630, 664, $750 \mathrm{~nm}$ wavelength and calculated according to the equation of Jeffrey and Humphrey [9].

For dry weight (DW) determination, the washed metaphyton was weighed, dried at $105^{\circ} \mathrm{C}$ for $24 \mathrm{~h}$ and weighed again.

\subsection{Primary Production}

\section{Plankton}

Phytoplankton primary production rate in the water column was measured monthly using the in situ light and dark oxygen bottle method [8]. Three sets of Triplicate $60 \mathrm{ml}$ Pyrex BOD bottles (Wheaton) were filled with Agmon water from the same sampler used for collecting water for Chl determination. Oxygen concentrations were measured by Winkler titrations [10]. The bottles were filled with a Tygon tube that reached the bottom of the bottle and were allowed to overflow with 3 times the volume of the bottle before being corked. The 3 bottles that served for determination of the initial oxygen concentration were immediately fixed by adding $0.6 \mathrm{ml}$ of Winkler reagents $1+2$. The light and dark bottles were incubated in situ at the original depth of sampling (mid-water column) for $1-4 \mathrm{~h}$, according to season. At the end of the incubation, the bottles were retrieved, placed in a dark container, and immediately fixed as above. After fixa- 
tion, all the bottles were kept in the dark in an ice box until arrival at the lab for determination of DO concentration. In the bottles to which Winkler $1+2$ reagents were already added, dissolved oxygen was determined by adding $0.6 \mathrm{ml}$ $\mathrm{H}_{2} \mathrm{SO}_{4}$ concentrated acid and titration with $719 \mathrm{~S}$ Titrino Metrohom instrument. Calculation of planktonic production was done according to Wetzel and Likens [11], and expressed in $\mathrm{mg} \cdot \mathrm{O}_{2} \cdot \mathrm{m}^{-2} \cdot \mathrm{h}^{-1}$.

\subsection{Benthos}

Benthic oxygen production or consumption rates were measured monthly at station 5 from March 1996-July 1997, and also at station 1 from January-July 1997, by following the changes with time in oxygen concentration in a bell jar system (Figure 2). The bell jar system used for measuring changes with time in DO concentrations within a confined volume of metaphyton (Figure 2), was made of a transparent plastic (PC $250 \mathrm{~mm}$ ) desiccator (Nalgene) from which the bottom was cut off to allow its insertion into the sediments. It covered $0.04 \mathrm{~m}^{2}$ of sediment surface and enclosed a volume of $4.5 \mathrm{l}$. Inner tubes and a hand pump were added for generating turbulence inside the jar, as well as a 60 -ml plastic syringe for collecting water samples for DO determination. The lower, open part of the desiccator was pressed into the sediment, and its upper part was closed under water, excluding air bubbles. The bell jar was incubated for $5-10 \mathrm{~min}$.

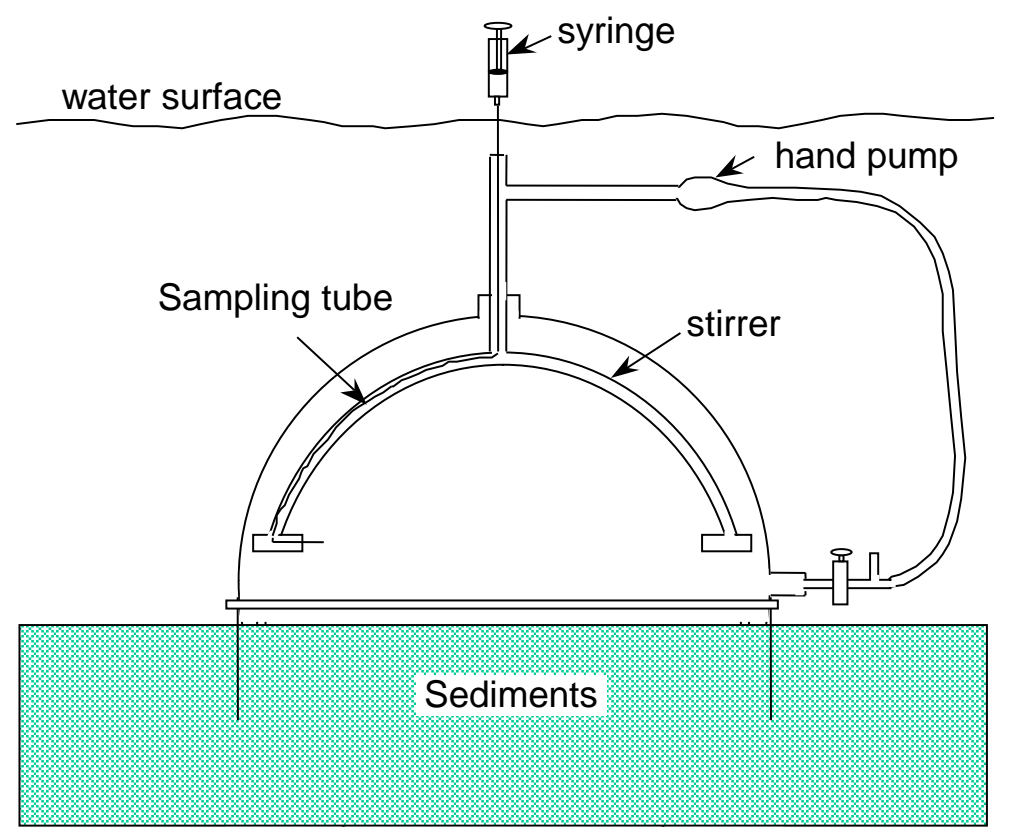

Figure 2. The bell jar system for measuring benthic algal primary production is a closed system made of a PC $250 \mathrm{~mm}$ desiccator (Nalgene) from which the bottom was cut off to allow its insertion into the sediments. Inner tubes and a hand pump were added to create inter-turbulence as well as a 60 $\mathrm{ml}$ plastic syringe for sampling. 
Sampling for DO determination at the beginning and end of incubation was made using $10 \mathrm{ml}$ glass BOD bottles. After fixation with Winkler reagents, the bottles were kept in a dark cold box until arrival at the lab for titration, as described for planktonic primary production. Primary production rate of the benthos was calculated in $\mathrm{mg} \cdot \mathrm{O}_{2} \cdot \mathrm{m}^{-2} \cdot \mathrm{h}^{-1}$ units. Because the water enclosed in the bell jar contained phytoplankton, benthos productivity was calculated as the difference between total productivity measured in the bell jar and areal phytoplankton productivity from the same station.

$$
\text { Equation (1). NP Benthos }=\frac{(L B-I B) \times V}{T \times S}-N P \text { Phytoplankton }
$$

where:

$N P=$ areal net production in $\mathrm{mg} \cdot \mathrm{O}_{2} \cdot \mathrm{m}^{-2} \cdot \mathrm{h}^{-1}$

$L B, I B=\mathrm{DO}$ concentration in light bottle or initial bottle, respectively, in $\mathrm{mg} \cdot \mathrm{L}^{-1}$

$V=$ bell jar volume, $(L)$.

$T=$ Incubation time, $(h)$.

$S$-Bell jar bottom surface area, $\left(\mathrm{m}^{2}\right)$.

\section{Results}

\subsection{Water Temperature}

During the study period, water temperatures ranged between $9.5^{\circ} \mathrm{C}$ (January 30 , 1997) and $30.8^{\circ} \mathrm{C}$ (May 15, 1997) (Figure 3(a)).

\subsection{Transparency and Light Penetration}

The seasonal changes in Secchi depth (Figure 3(b)) reflected the dynamics of the phytoplanktonic population: during winter and spring, Secchi depth reached the bottom sediments at $0.8 \mathrm{~m}$, typical of a clear-water phase. Shallow Secchi depth, averaging $0.3 \mathrm{~m}$, was measured during the summer and autumn phytoplankton bloom phase (August till December, 1996). These findings corresponded to the light attenuation profiles in the water column (Figure 4). On March 18, 1996, under clear-water conditions, about $60 \%$ of the incident radiation reached the bottom sediments, whereas during the summer phytoplankton blooms (September 17,1996$)$ practically all the incident light was attenuated within the upper $30-40 \mathrm{~cm}$. The $\%$ irradiance at subsurface $(0-60 \mathrm{~cm}$ depth) in summer and winter profiles are presented in Figure 4 plotted on one scale of \% (0 100).

\subsection{Diel Changes in $\mathrm{O}_{2}$ Concentration and Temperature}

At the beginning of the sampling period (January 1997), the DO concentration was $10.2 \mathrm{mg} \cdot \mathrm{O}_{2} \cdot \mathrm{L}^{-1}$ at station 5 and $10.6 \mathrm{mg} \cdot \mathrm{O}_{2} \cdot \mathrm{L}^{-1}$ at station 1 . During the research period, DO in the water column ranged between 5.3 and $15.3 \mathrm{mg} \cdot \mathrm{O}_{2} \cdot \mathrm{L}^{-1}$. The highest diel change in $\mathrm{DO}$ concentration $\left(2.2 \mathrm{mg} \cdot \mathrm{O}_{2} \cdot \mathrm{L}^{-1}\right)$ was recorded in May in Station 1. In January-February, DO concentration in the water column 


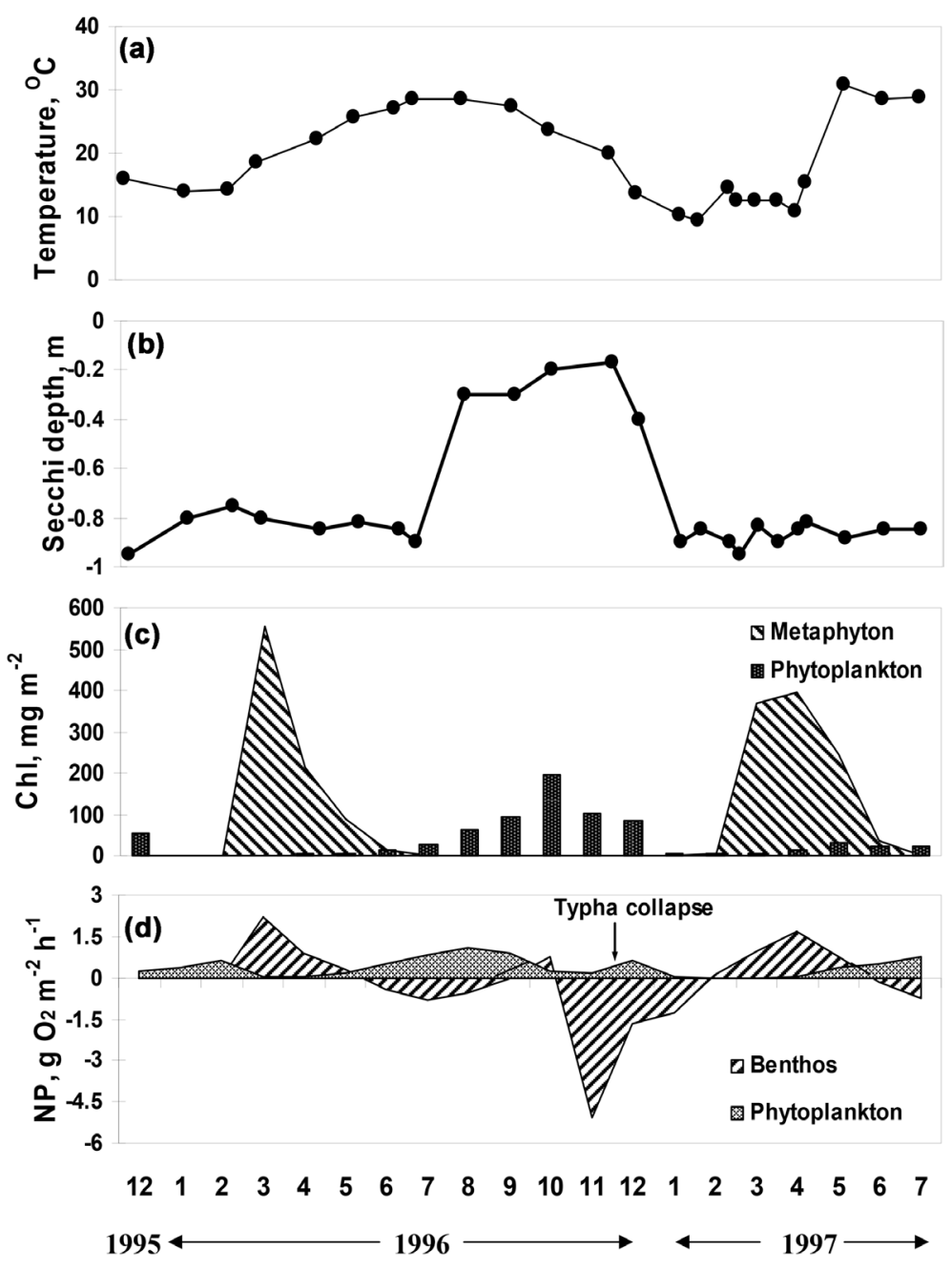

Figure 3. Seasonal changes in water parameters at Station 5, December 1995 July 1997: (a) temperature (SD's < 20\%); (b) Secchi depth (SD's < 30\%); (c) phytoplankton and metaphyton chlorophyll $a$; and (d) phytoplankton and benthos primary production.

decreased with depth. During the metaphyton bloom period between March and May, $\mathrm{O}_{2}$ concentration in the water increased with depth, and concentration at the bottom was $3 \mathrm{mg} \cdot \mathrm{O}_{2} \cdot \mathrm{L}^{-1}$ higher than at the water surface (Figure 5).

The highest diel change in water temperature, $3.8^{\circ} \mathrm{C}$, was recorded in May at station 1 , where average air temperature was $29.4^{\circ} \mathrm{C}$, and the lowest diel change, $0.1^{\circ} \mathrm{C}$, was recorded in January at station 1 , where average air temperature was $10^{\circ} \mathrm{C}$ (Figure 5).

\subsection{Biomass}

\section{Phytoplankton}

During the study period, an inverse relationship between phytoplankton and metaphyton Chl was obtained. A relatively low mean phytoplankton Chl value of $2.5 \mathrm{mg} \cdot \mathrm{m}^{-2}$ characterized the water column concentrations from January to May 
$\%$ Irradiance at subsurface

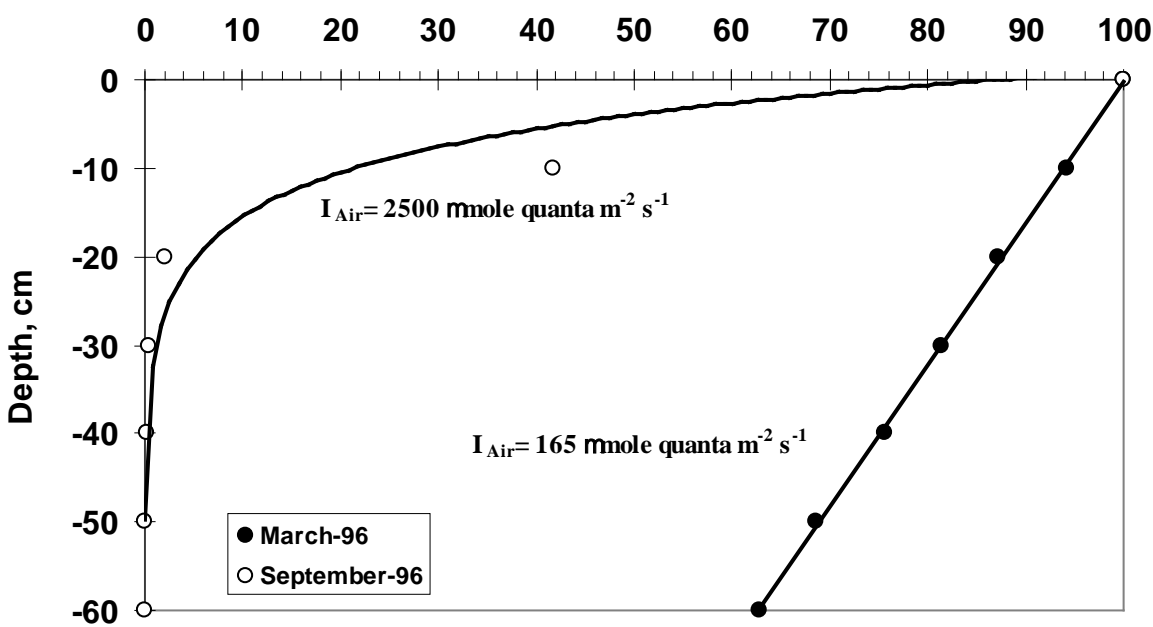

Figure 4. Representative depth profiles of light penetrations in Lake Agmon: in summer (September 17, 1996, surface irradiance $=2500 \mu \mathrm{mol} \cdot$ quanta $\cdot \mathrm{m}^{-2} \cdot \mathrm{s}^{-1}$ ) when dense phytoplankton blooms caused severe attenuation, and during the winter clear-water phase (March 18, 1996, surface irradiance $=165 \mu \mathrm{mol} \cdot$ quanta $\cdot \mathrm{m}^{-2} \cdot \mathrm{s}^{-1}$ ), when light reached the bottom.

1996 (Figure 3(c)) followed by an increase in June. High Chl levels were maintained till December 1996, with maximal value of $195.5 \mathrm{mg} \cdot \mathrm{m}^{-2}$ on October 14, 1996. By January 14, 1997, phytoplankton Chl declined below $4.3 \mathrm{mg} \cdot \mathrm{m}^{-2}$. This seasonal pattern was repeated during the following year.

\section{Metaphyton}

During the two spring seasons (March-June 1996 and February-June 1997) when light reached the bottom of Lake Agmon, a massive bloom of benthic algal filaments was observed (Figure 4). Benthic algae were characterized by randomly-distributed patchiness [6]. The results measured during the study period ranged between values of 5 and $700 \mathrm{mg} \cdot \mathrm{Chl} \cdot \mathrm{m}^{-2}$ and demonstrated remarkable spatial and temporal variability due to the characteristic patchiness of the benthic algae. The dominant benthic bloom taxon in 1996 was initially Spirogyra, which was later replaced by Oedogonium. In 1997, the bloom-forming genus was Cladophora. A comparison between sampling years (1996 and 1997) showed similar patterns in Chl concentration (Figure 6). The obvious relation between Chlorophyll a and wet and dry matter (biomass) was accounted. Maximal values of $554 \mathrm{mg} \cdot \mathrm{Chl} \cdot \mathrm{m}^{-2}$ and $701 \mathrm{mg} \cdot \mathrm{Chl} \cdot \mathrm{m}^{-2}$ were recorded during March 1996 and April 1997, respectively, followed by a sharp decrease to a mean value of 43 $\mathrm{mg} \cdot \mathrm{Chl} \cdot \mathrm{m}^{-2}$ during the June months of both years.

Benthos dry weight (DW) was also expressed per unit surface area of $\mathrm{m}^{2}$ (Figure 7). A correlation between the dry weight and Chl concentration was demonstrated by similar temporal trends of the two parameters. Therefore, Chl may serve as a useful tool for representing changes in metaphyton biomass. Maximal values of $548 \mathrm{~g} \cdot{ }_{\mathrm{DW}} \cdot \mathrm{m}^{-2}$ and $720 \mathrm{~g} \cdot{ }_{\mathrm{DW}} \cdot \mathrm{m}^{-2}$ were recorded during March 


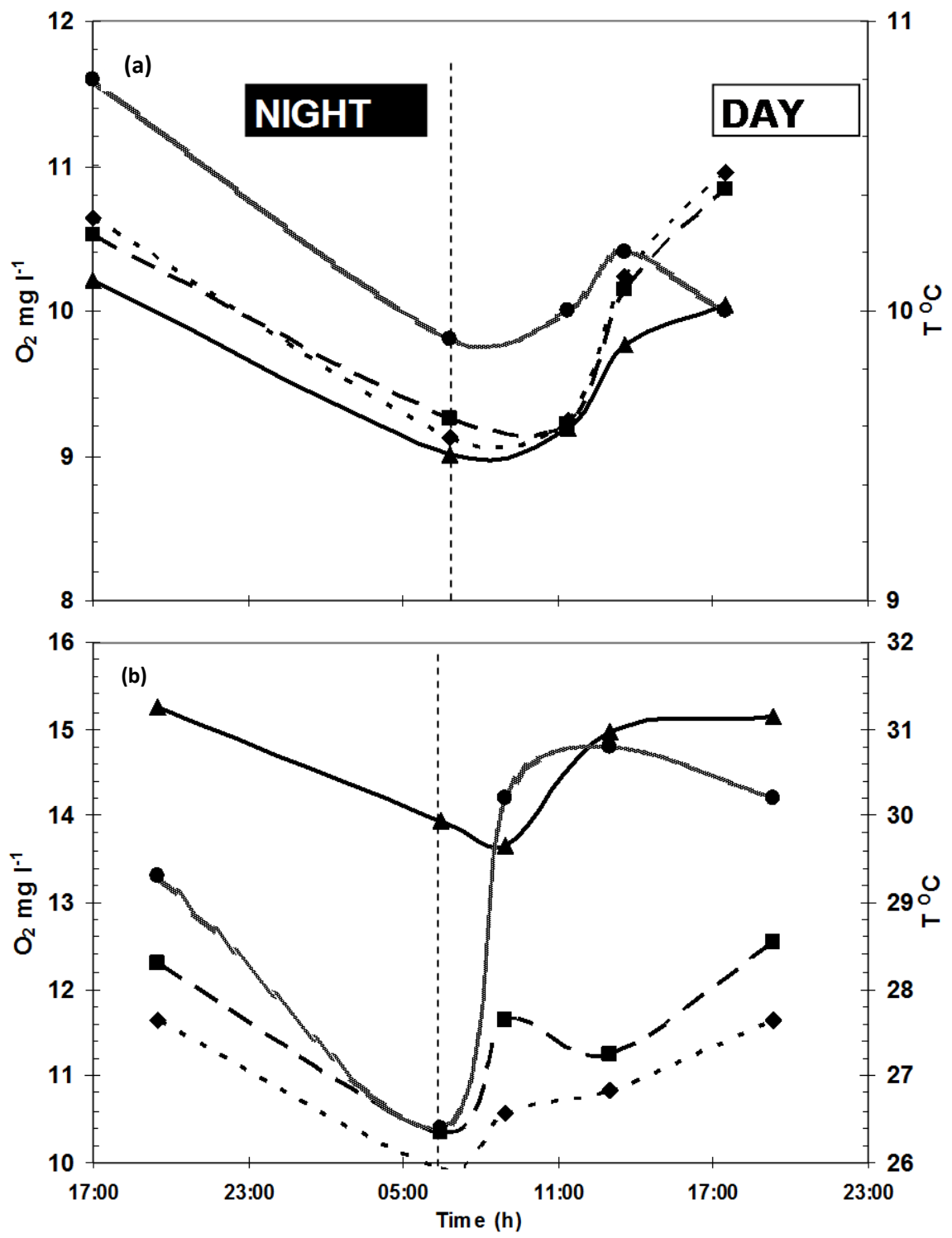

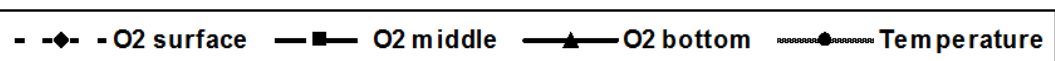

Figure 5. Diel fluctuations in DO concentrations at 3 depths in the water column: sub-surface, middle, and just above the sediments on (a) January 30; and (b) May 14, 1997. Also shown is the water temperature at the middle of the water column.

1996 and April 1997, respectively. In the 1997 measurements, the biomass of benthic filamentous at Station 5 was 50\% lower compared with 1996. During the summer sampling (both years), 95\% and 92.5\%, respectively, lower values were found.

\subsection{Primary Production}

\section{Plankton}

The rate of phytoplankton primary production in the lake was characterized by a seasonal cycle. The initial primary production values measured in 

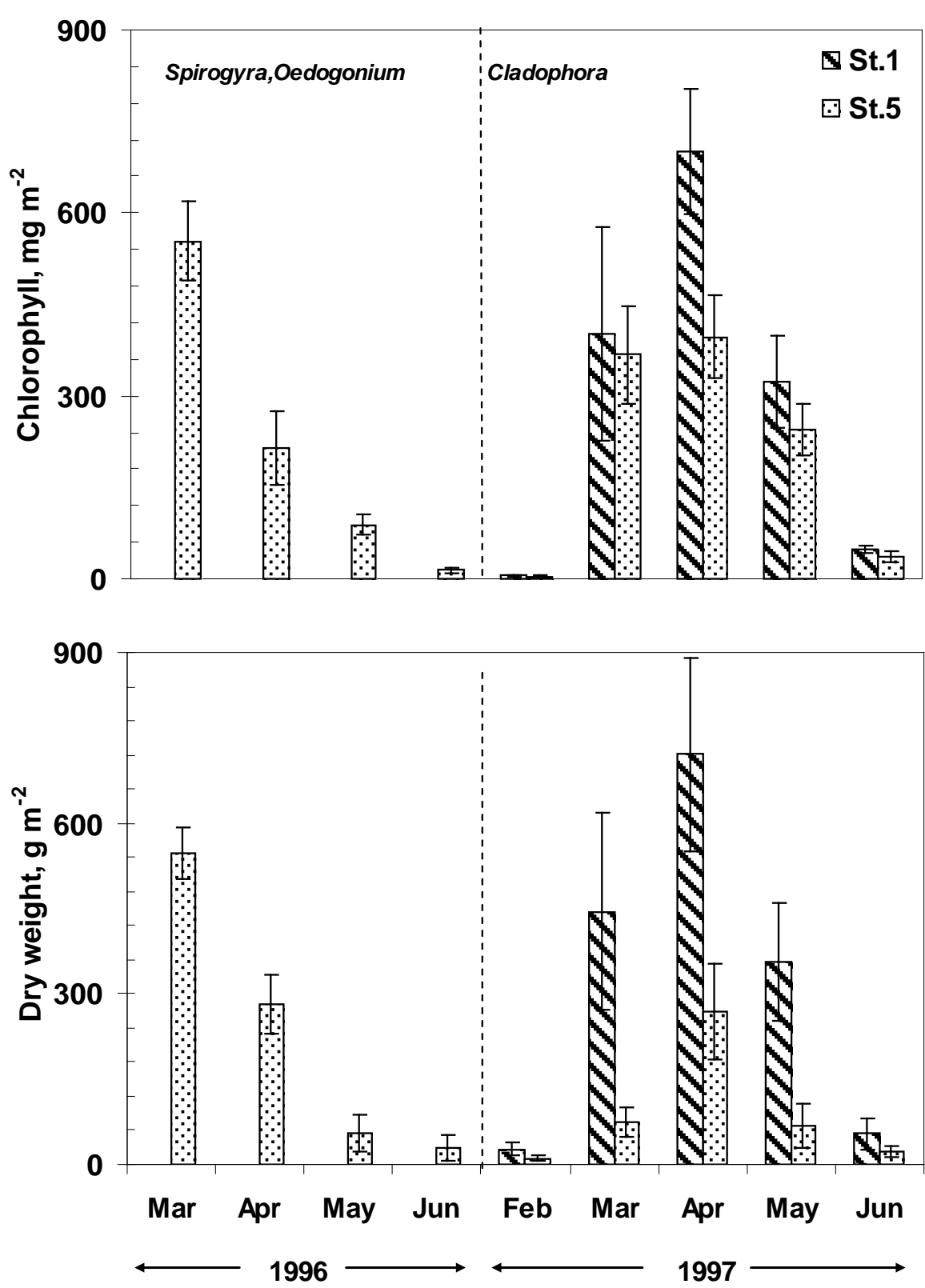

Figure 6. Dial changes in average $\pm \mathrm{SD}(\mathrm{N}=5)$ chlorophyll a concentration and algal dry weight during the metaphyton bloom seasons, in 1996 (Station 1) and 1997 (stations 1 and 5). Dominant algal taxa are shown.

December 1995 at stations 2 and 5 were 90 and $260 \mathrm{mg} \mathrm{O} \cdot \mathrm{m}^{-2} \cdot \mathrm{h}^{-1}$, respectively (Figure 3(d)). A decrease of $84 \%-93 \%$ throughout the winter was followed by an increase in summer 1996, as expressed by peak values of 1200 and 850 $\mathrm{mg} \cdot \mathrm{O}_{2} \cdot \mathrm{m}^{-2} \cdot \mathrm{h}^{-1}$ at stations 2 and 5 , respectively, on July 8,1996 . During the following winter, a gradual decrease to about $7 \mathrm{mg} \cdot \mathrm{O}_{2} \cdot \mathrm{m}^{-2} \cdot \mathrm{h}^{-1}$ was recorded, followed by increment to levels of $788 \mathrm{mg} \cdot \mathrm{O}_{2} \cdot \mathrm{m}^{-2} \cdot \mathrm{h}^{-1}$ from May 1997.

\section{Benthos}

The dynamics of benthic primary production were inverse to planktonic primary production (Figure $3(\mathrm{~d})$ ); when planktonic production was high, benthic 


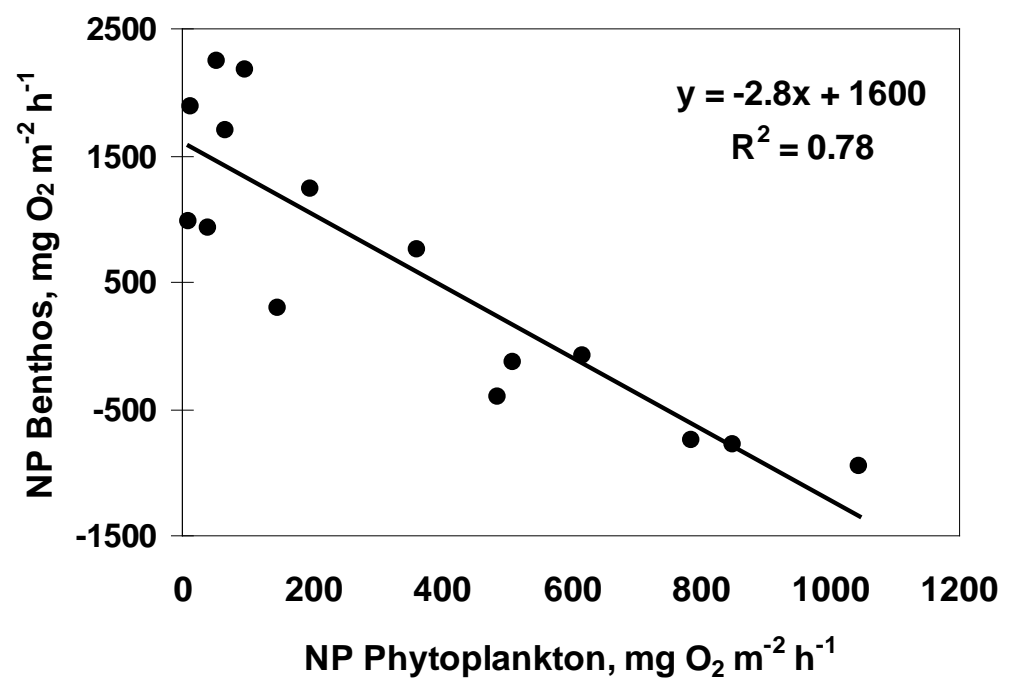

Figure 7. The inverse relationship between phytoplankton and benthos net primary production during the study period. $(\mathrm{NP}=$ Net Production $)$

production was low, and vice versa $\left(\mathrm{r}^{2}=0.78, \mathrm{p}<0.01, \mathrm{n}=15\right.$, Figure 7$)$. The inverse relation between Net-Primary Production of the Phytoplankton and the benthic communities represent the summer collapse of the benthic mats.

Relatively high benthic production was recorded during the spring (March-June) metaphyton dominance phase, with maximal values of 2240 and $1700 \mathrm{mg} \cdot \mathrm{O}_{2} \cdot \mathrm{m}^{-2} \cdot \mathrm{h}^{-1}$ found on March 18, 1996 and April 10, 1997, respectively. After the summer collapse of the benthic mats and until January of the following year, net benthic production was negative, i.e., oxygen consumption exceeded oxygen production in our bell-jar experiments. This was expressed by values of -781 and $-5109 \mathrm{mg} \mathrm{O}_{2} \cdot \mathrm{m}^{-2} \cdot \mathrm{h}^{-1}$ recorded in July and November 1996 , respectively.

Primary productivity values of the benthic algae were corrected for plankton production but not for oxygen demand at the bottom. Therefore, values may actually be higher than those presented.

Oxygen demand at the bottom during a period when no benthos algae were recorded was $3022 \mathrm{~g} \cdot \mathrm{O}_{2} \cdot \mathrm{m}^{-2} \cdot$ year $^{-1}$, while the average rate of oxygen consumption per month at the bottom was $377 \mathrm{~g} \cdot \mathrm{O}_{2} \cdot \mathrm{m}^{-2} \cdot \mathrm{month}^{-1}$, or $12.5 \mathrm{~g} \cdot \mathrm{O}_{2} \cdot \mathrm{m}^{-2} \cdot \mathrm{day}^{-1}$. Assuming that bottom-oxygen demand was relatively constant over the year, the corrected benthic production was estimated at $2825 \mathrm{~g} \cdot \mathrm{O}_{2} \cdot \mathrm{m}^{-2} \cdot \mathrm{year}^{-1}$.

\section{Discussion}

Primary production is the major biological process in ecological systems playing a crucial role in their maintenance, stability and sustainability. The seasonal and inter-annual dynamics of photosynthetic components and their biomass serve as indicators tracing seasonal patterns and long-term trends in the ecosystem. Two main algal groups functioned as the main components influencing the seasonal dynamics of Lake Agmon: the phytoplankton and the metaphyton. 
The dynamics of the phytoplankton and metaphyton are controlled by seasonal changes in radiation, temperature, and nutrient levels which determined the outcome of the competitive relations between these groups, and by their interaction with respective zooplanktonic grazers. The annual cycle of both components in Lake Agmon was first indicated by Zohary et al. [6]. The present study describes in detail the seasonal changes in biomass distribution and primary production between the benthic and planktonic components.

Phytoplankton dominated the Agmon algal biomass in summer and fall, and its annual course was the opposite of that of the benthos.

The metaphyton bloom developed according to the following pattern: the benthic algae became visible in February, and its cover became increasingly conspicuous during spring, until peaking in April. The relatively large standard deviation apparent in the biomass data of the dominant benthic algae (Figure 6) illustrates the patchy distribution of Lake Agmon metaphyton. After that time, a process began in which gas bubbles became trapped underneath the mats and caused parts of those mats to detach and rise to the surface. The source of the gas bubbles was photosynthetically-produced oxygen at super-saturation levels. This phenomenon was noted by others [12] [13].

As water temperatures increased, the water became super-saturated with oxygen at a lower concentration. In Agmon, water temperature reached $30.8^{\circ} \mathrm{C}$ on May 14 (Figure 3(a), Figure 5). At such temperature, DO concentration in the water column was $11.25 \mathrm{mg} \cdot \mathrm{L}^{-1}$, whereas oxygen saturation solubility was 7.42 $\mathrm{mg} \cdot \mathrm{L}^{-1}$. Evidently, at this high concentration, oxygen bubbles were formed. The floating mats were subjected to high light (over $2000 \mathrm{~mol}$ quanta $\mathrm{m}^{-2} \cdot \mathrm{s}^{-1}$ ), high temperature, and high oxygen concentration levels at the surface, resulting in free radical formation and death due to photo-oxidation [6]. Furthermore, the floating algae caused strong shading and reduced light penetration to the bottom, which further enhanced the rate of decay of the remaining attached mats. This phenomenon is characteristic of metaphyton elsewhere in the world [12] [13] [14] [15]. In temperate climates, during cloudy days with low productivity, bubble production is reduced and the mats sink [12]. In the Hula Valley in spring, however, practically all days are sunny and the mats remain at the surface for days. The death of metaphyton and their subsequent mineralization releases nutrients to the water. Of these, as is typical of many peat lakes, nitrogen is in excess of phosphorus, and indeed, the phytoplankton bloom in Lake Agmon reflects phosphorus, (not nitrogen) availability [6].

\section{Biomass and Primary Production}

In order to evaluate the relative contribution of the two algal groups to the total biomass, timing integration of a full year cycle was evaluated. Our findings indicate that although the period of the benthos bloom was relatively short in comparison to the planktonic algal bloom, its contribution to the total chlorophyll over the annual cycle $\left(870 \mathrm{mg} \cdot \mathrm{m}^{-2} \cdot \mathrm{yr}^{-1}\right)$ was 1.5 times higher than that of the planktonic chlorophyll (588 $\mathrm{mg} \cdot \mathrm{m}^{-2} \cdot \mathrm{yr}^{-1}$ ) (Figure $3(\mathrm{c})$ ). 
The findings of our study are similar to those reported from the Everglades, also a peat bottom water body in Florida [16]. Benthic biomass in the Everglades varied between the extremes of 2 and $2682 \mathrm{~g} \cdot \mathrm{dry} \cdot$ weight $\cdot \mathrm{m}^{-2}$ [5] [15]. The work of Wood and Maynard [17] showed that filamentous algal biomass in the Everglades reached up to $5960 \mathrm{~g} \cdot \mathrm{dry} \cdot$ weight $\cdot \mathrm{m}^{-2}$ [18]. In Delta Marsh in the shallow Lake Manitoba in Canada, phytoplankton biomass varied between 0.5 $\mathrm{mg} \cdot \mathrm{Chl} \cdot \mathrm{m}^{-2}$ and $39.3 \mathrm{mg} \cdot \mathrm{Chl} \cdot \mathrm{m}^{-2}$. Filamentous algal biomass, which was dominated by Spirogyra and Oedogonium, varied between 123 and $1309 \mathrm{mg} \cdot \mathrm{Chl} \cdot \mathrm{m}^{-2}$ [13]. In Lake Manitoba, the phytoplankton contributed only $1 \%$ of total Chl, whereas in Lake Agmon it ranged between 3.2 and $802 \mathrm{mg} \cdot \mathrm{chl} \cdot \mathrm{m}^{-2}$ and contributed over $30 \%$ of the total plant biomass.

In addition to the biomass ratios described above, we attempted to quantify the relative contribution of the two different algal groups to the total annual algal primary production. The annual phytoplanktonic primary production during the study period was 1340 and 2030, g. $\mathrm{O}_{2} \cdot \mathrm{m}^{-2} \cdot \mathrm{year}^{-1}$ at Stations 2 and 5, respectively, whereas the mean primary productivity rates of the benthic algae during the same period was 1350 and $2100 \mathrm{~g} \cdot \mathrm{O}_{2} \cdot \mathrm{m}^{-2} \cdot \mathrm{year}^{-1}$ at the same stations. These data shows that even though the benthic primary producers are active only during a relatively brief period (March-June), their annual contribution to primary productivity was nearly equal to that of the planktonic component. It is noteworthy that excluding the Typha-induced respiration discussed below; a significant fraction $(\sim 72 \%)$ of the benthic annual gross production was consumed by intense respiration.

Our results support the findings of Robinson et al. [13] working in the Delta Marsh of Lake Manitoba, Canada, who found a similar range (63 - 790 $\mathrm{C} \cdot \mathrm{m}^{-2} \cdot \mathrm{year}^{-1}$ ) of benthic primary production rates.

The value of $-5109 \mathrm{mg} \cdot \mathrm{O}_{2} \cdot \mathrm{m}^{-2} \cdot \mathrm{h}^{-1}$ measured on November 27, 1996, was supposedly contributed by the flush of respiration induced by the availability of substrates after the Typha domingensis collapse that occurred around that time [19]. Nevertheless, other studies [20] [21] concluded different causation for the Typha die-off, nutritional (Phosphorus and Nitrogen) deficiency. However, the total collapse of a large biomass of rooted vegetation, mostly Typha domingensis and associated plants, made a massive amount of decaying plant material available as substrate for respiration, thus explaining the peak value measured in November. This value far exceeded that possible for respiration of the algal benthos alone.

In this context, we considered the contribution of two different algal groups to the biological and functional activity of a water body. Primary production values obtained in this study were analyzed by three aspects: time sequence, biomass and ecosystem functioning. This finding emphasizes the relatively large contribution of metaphyton population blooming during a short period to the dynamics of the Lake Agmon ecosystem.

\section{Conclusive Summary}

We propose that the seasonal shift of dominance between phytoplankton and 
benthos is directed as follows: benthic algae, whenever present, will outcompete and exclude phytoplankton by sequestering available nutrients when these are relatively plentiful, while phytoplankton prevails under the lower nutrient concentrations in summer [1]. It is plausible that there may also be allelopathic interference of the benthos with phytoplankton proliferation. Such cases were described in relation to allelopathic interactions between submerged macrophytes (Chara) and planktonic green algae [22] and between phytoplankton species [23]. In the summer, as temperatures rise, the metaphyton canopy collapses and decomposes due to photodynamic damage and the resulted free radicals. Mineralization of the algal mats releases nutrients and their disappearance makes light available, setting the stage for the ensuing phytoplankton development. Recent data of routine monitoring program confirm conclusions about phytoplankton spatial and temporal density distribution [24].

\section{Acknowledgements}

The authors are warmly thanking Prof.'s Z. Dubinsky and T. Zohary for supervising the study and evaluation of the results. Deep thanks are given for technical assistance in field work supported by James Easton, Bina Kaplan, and Ezra Yasur which was very helpful and friendly. Special thanks to B Lazar and D. Markel for their assistance with construction of the bell jar system, and to A. Parparov for assistance with oxygen analyses.

\section{References}

[1] Gophen, M., Meron, M., Tsipris, Y., Orlov-Levine, V. and Peres, M. (2016) Chemical, Hydrological and Climatological Properties of Lake Agmon, Hula Valley (Israel), (1994-2006). Open Journal of Modern Hydrology, 6, 18.

[2] Gophen, M. (2016) The Hula Valley (Israel): From Nature to Anthropogenic Management, A Review. Review of Social Sciences, 1, 1-10. https://doi.org/10.18533/rss.v1i7.42

[3] Hambright, K.D., Bar-Ilan, I. and Eckert, W. (1998) General Water Chemistry and Quality in a Newly-Created Subtropical Wetland Lake. Wetlands Ecology and Management, 6, 121-132. https://doi.org/10.1023/A:1008484506420

[4] Markel, D., Sass, E., Lazar, B. and Bein, A. (1998) Biogeochemical Evolution of a Sulfur-Iron Rich Aquatic System in a Reflooded Wetland Environment (Lake Agmon, Northern Israel). Wetlands Ecology and Management, 6, 103-120. https://doi.org/10.1023/A:1008407800060

[5] Gleason, P.J. and Spackman, W. (1974) Calcareous Periphyton and Water Chemistry in the Everglades. In Gleason, P.J., Ed., Environments of South Florida Present and Past, Miami Geological Society, Coral Gables, 146-181.

[6] Zohary, T., Fishbein, T., Kaplan, B. and Pollingher, U. (1998) Phytoplankton - Metaphyton Seasonal Dynamics in a Newly Created Subtropical Wetland. Wetlands Ecology and Management, 6, 133-142. https://doi.org/10.1023/A:1008428305512

[7] Sverdrup, H.U., Johanson, M.W. and Fleming, R.H. (1942) The Oceans. Prentice Hall, Englewood Cliffs, NJ.

[8] Strickland, J.D.H. and Parsons, T.R. (1972) A Practical Handbook of Seawater Analysis. Fisheries Research Board of Canada, Ottawa. 
[9] Jeffrey, S.W. and Humphrey, G.F. (1975) New Spectrophotometric Equations for Determining Chlorophylls $a, b, c_{1}$ and $c_{2} \mathrm{n}$ Higher Plants, Algae and Natural Phytoplankton. Biochemie und Physiologie der Pflanzen, 167, 191-194. https://doi.org/10.1016/S0015-3796(17)30778-3

[10] APHA. (1995) Standard Methods for Examination of Water and Wastewater. 19th Edition, American Public Health Association, New York.

[11] Wetzel, R.G. and Likens, G.E. (1990) Limnological Analyses. 2nd Edition, Springer-Verlag, NY.

[12] Crumpton, W.G. (1989) Algae in Northern Prairie Wetlands. In: Van-Der Valk, A., Ed., Northern Prairie Wetlands, Iowa State University, Ames, 188-203.

[13] Robinson, G.G.C., Gurney, S.E. and Goldsborough, L.G. (1997) Response of Benthic and Planktonic Algal Biomass to Experimental Water-Level Manipulation in a Prairie Lakeshore Wetland. Wetlands, 17, 167-181. https://doi.org/10.1007/BF03161407

[14] Hillebrand, H. (1983) Development and Dynamics of Floating Clusters of Filamentous Algae. In: Wetzel, R.G., Ed., Periphyton of Freshwater Systems, Developments in Hydrobiology, Dr. W. Junk, The Hague, 31-39. https://doi.org/10.1007/978-94-009-7293-3_7

[15] Browder, J.A., Cottrell, D., Brown, M., Newman, M., Edward, R., Yuska, J., Browder, M. and Krakoski, J. (1982) Biomass and Primary Production of Microphytes and Macrophytes in Periphyton Habitats of Southern Everglades. Report T-662. South Florida Research Center, Homestead, Florida.

[16] Rader, R.B. and Richardson, C.J. (1992) The Effects of Nutrient Enrichment on Algae and Macroinvertebrates in the Everglades-A Review. Wetlands, 12, 121-135. https://doi.org/10.1007/BF03160593

[17] Wood, E.J.F. and Maynard, N.G. (1974) Ecology of the Microalgae of the Florida Everglades. In: Gleason, P.J., Ed., Environments of South Florida Present and Past, Miami Geological Society, Coral Gables, 123-145.

[18] Davis, S.M. and Ogden, J.C. (1994) Everglades, the Ecosystem and Its Restoration. St. Lucie Press, Delray Beach.

[19] Ashkenazi, S., Markel, D. and Kaplan, D. (1999) The Catastrophic Decline of Cattail Typha domingensis in Lake Agmon: Possible Mechanisms and Remedial Measures. Journal of Mediterranean Ecology, 1, 85-100.

[20] Gophen, M. (2000) Nutrient and Plant Dynamics in Lake Agmon Wetlands (Hula Valley, Israel): A Review with Emphasis on Typha domingensis (1994-1999). Hydrobiologia, 441, 25-36. https://doi.org/10.1023/A:1017525804657

[21] Simhayov, R., Litaor, M.I., Barnea, I. and Shenker, M. (2011) The Catastrophic Dieback of Typha domingensis in an East Mediterranean Altered Wetland: Model Revisit. Mires and Peat, 9, 1-12. http://www.mires-and-peat.net/

[22] Mulderij, G., Van Donk, E. and Roelofs, J.G.M. (2003) Differential Sensitivity of Green Algae to Allelopathic Substances from Chara. Hydrobiologia, 491, 261-271. https://doi.org/10.1023/A:1024483704903

[23] Hulot, F.D. and Huisman, J. (2004) Allelopathic Interactions between Phytoplankton Species: The Roles of Heterotrophic Bacteria and Mixing Intensity. Limnology and Oceanography, 49, 1424-1434.

https://doi.org/10.4319/lo.2004.49.4_part_2.1424

[24] Barnea, I. (2006-2016) Annual Reports, Hula Project-Monitor Program, Keren Kayemet Le'Israel (JNF) and Water Authority. 